\title{
ENVIRONMENTAL IMPACT OF MINE WATER, UTILIZATION AND MANAGEMENT IN INDIAN MINES
}

\author{
Saba Shirin* and Aarif Jamal \\ Department of Mining Engineering, \\ Indian Institute of Technology (Banaras Hindu University), Varanasi-221 005, India \\ *E-mail : sabashirin83@gmail.com
}

\begin{abstract}
Mine water in coal mines is a common problem and its availability increases with depth. The disposal of wastewater from mines is one among the most important problems associated with coal mining operations. As a result of mining, both quality and quantity of water are severely affected. The paper has been conducted to assess the quality of water sump and its subsequent utilization in mines and other purposes. It may be concluded from the above study that the $\mathrm{pH}$, TDS, and TSS of water is varying from one point to another point along with other objectionable parameters. Until recently all pollution abatement efforts are aimed at controlling mine wastewater discharge into receiving waters. This paper focused on utilization and management of mine water treatment also.

Keywords: Environment; Physico-chemical characteristics; Mine Water; Open cast mine.
\end{abstract}

(C) RASĀYAN. All rights reserved

\section{INTRODUCTION}

The environmental problems associated with are air pollution, water pollution (both surface as well as subsurface), soil pollution and land degradation, noise or sound pollution etc. Among these, the water is most vulnerable to change its quality ${ }^{1}$. Mining requires large amounts of water for coal preparation plants and dust suppression and equipment washing ${ }^{2}$.

The occurrence of water in the coal mine is most common. The availability of water in mines are essential to meet the requirement of dust suppression, washing of equipment and washing plantation etc. On the other hand interaction of water with coal and associated rocks and causes various environmental problem $^{3}$. The occurrence of acid mine drainage is not an uncommon issue in coal mines of India. The problem of acid mine drainage generation exists in most of the coal mines and many metal mines.

Protection of water quality, the original purpose of pollution control continues to be the primary main objective in the mining industry at present. However, preservation of water resources, protection of physio-chemical of downstream and maintenance of recreational water are additional priorities in and around a mining industry. In order to prepare a water management action plan, water quality assessment of various mining projects is an integral part and has been conducted properly at fixed duration.

The quality of mine water depends upon the amount of rainfall, the reactivity of rocks through which the water flows, porosity and permeability of rocks, interaction duration between water and the rocks, types of mining machinery, production of the dust and fine particles of rocks, and many other factors. The types of pollutants generated from the coal mining operation are principally minerals in coal and coalassociated rocks, which are dissolved in water while they come in contact with later.

\section{EXPERIMENTAL}

\section{Study Area}

Singrauli Coalfield is spread across the districts of Singrauli and Sonebhadra in the Indian states of Madhya Pradesh and Uttar Pradesh, mostly in the basin of the Son River. It is spread over nearly 2,200 $\mathrm{km}^{2}$ but only a small part of the coalfield, around $220 \mathrm{~km}^{2}$, has been identified as promising by the Geological Survey of India. The north-eastern part of the coalfield sits on a plateau with an altitude of 500 
$\mathrm{m}$ above mean sea level, well above the lower plains of $280 \mathrm{~m}$ altitudes. Northern Coalfields Limited was carved out of Central Coalfields Limited in 1986, to take care of operations in the Singrauli Coalfield. The proved reserves in the Moher basin are about 3 billion tonnes out of which 2.3 billion tones have already been planned for mining, in an area of about $84 \mathrm{~km}^{2}$ shown in figure 1 with the coordinate of $24^{\circ} 10^{\prime} 51.34^{\prime}$ 'N and $85^{\circ} 45^{\prime} 00.36^{\prime}$ 'E.

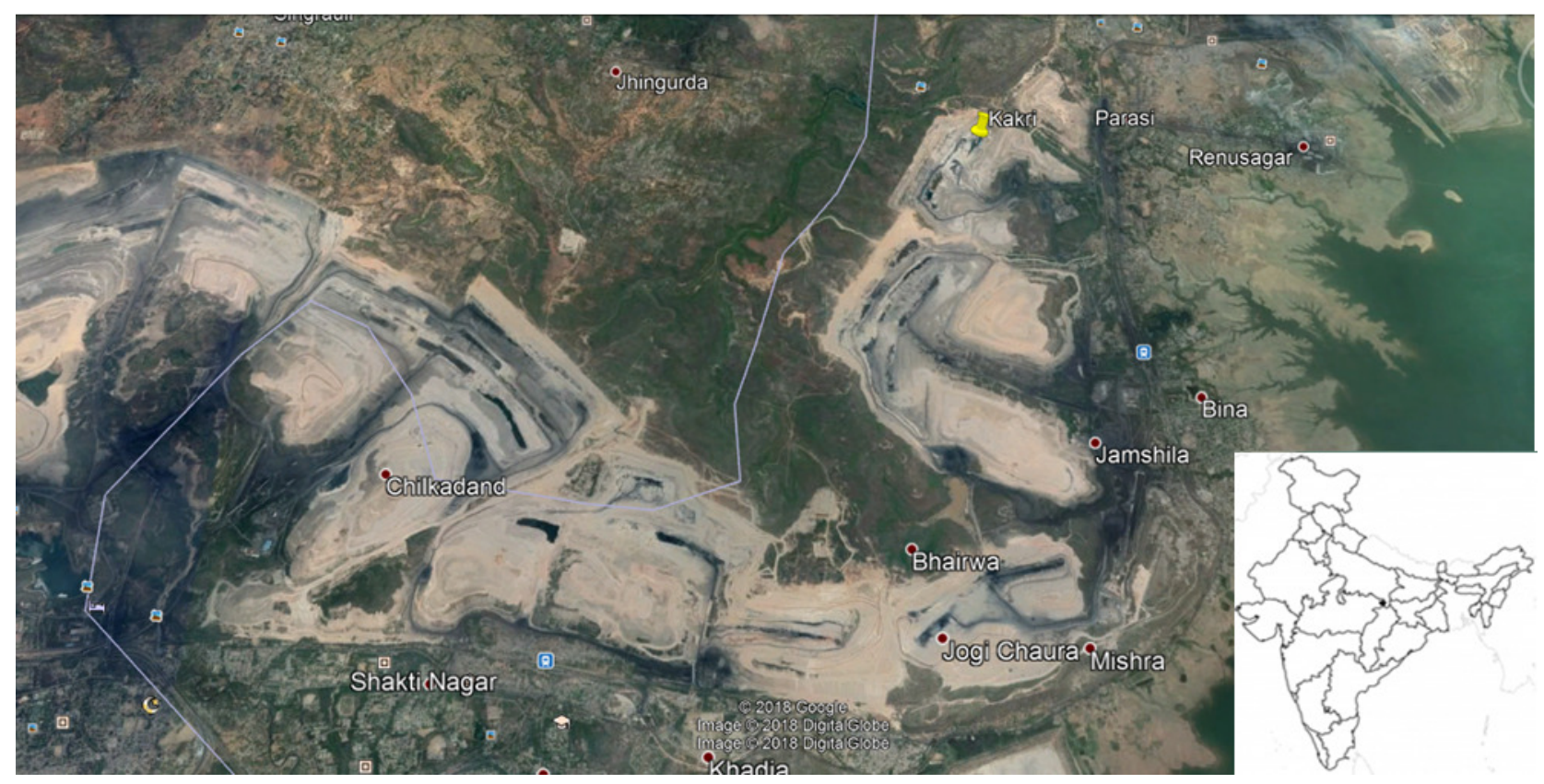

Fig.-1: Location of the Study Area

The Singrauli coal field stands as high plateau over the surrounding planes covered by Talchir sediment. The Barakar sediment projects over the Talchir outcrops as scrap faces. Towards North, the Gondwana sediment abuts against Precambrian rocks, which form a series of East-West trending prominent ridge. The Singrauli plateau rises to a height of over $500 \mathrm{~m}$ above mean sea level from the Southern plane, which has a general level of about $275 \mathrm{~m}$ from above mean sea level.

The plateau, which is referred to as Mohar plateau, has step-like scrap faces towards the south. The steps appear to represent different stages of peneplanation. The different platforms are of a remnant type, resulting from erosion of gently inclined sedimentary strata of varying resistance. Physiographically, the eastern part of the coalfield in U.P., is characterized by a cluster of hills and plateau to the north and undulating plains to the south. The western part of the coalfield also comprises a platform with a slope towards east and south, where there are abrupt drops of 50 to $60 \mathrm{~m}$ in altitude. Towards southwest, several high peaks such as Popari and Burma are prominent topographic features.

The coalfield experiences a tropical monsoon type climate. Though, the winters are rather cold $\left(5-10^{\circ} \mathrm{C}\right)$, the summer temperature often shoots up to $46^{\circ} \mathrm{c}$ in the daytime. The area enjoys a rather heavy monsoon and the annual rainfall varies between $125 \mathrm{~cm}$ and $150 \mathrm{~cm}$.the wild animals are depleting and many have migrated to more remote areas due to mining and allied activities. The ground especially the elevated areas, is mostly covered with open forests of Kendu, Mahua, Bija, Amla, and Palash while the flat terrain is deforested for cultivation and mining operation.

\section{Material and Methods}

\section{Location and Description of Water Sampling Sites}

The water sampling locations were identified with the objective to assess the physicochemical characteristics of mine water across the mine. The mines have two sumps and two workshops Effluent 
(table 1). From each place, the representative samples of mine water were taken from the different location of the same sump and workshop. The water samples hence were collected to ensure that it must be both homogeneous and representative and Physico-chemical properties of the water must not be changed during collection and analysis. The time of sampling of mine water is also an important factor because the nature of water samples in mine varies due to washing schedule of mine machinery, change in shift etc. However, in this investigation, water samples were collected between 10 a.m. to 1 p.m. during the day. The water samples were collected in plastic gallons (figure 2) because they can be easily handled, inorganically inactive and durable. Manual sampling has been done during water quality survey. Due care was taken during sampling and transportation of these samples. The sample collection technique adopted was in accordance with the nature of water bodies.
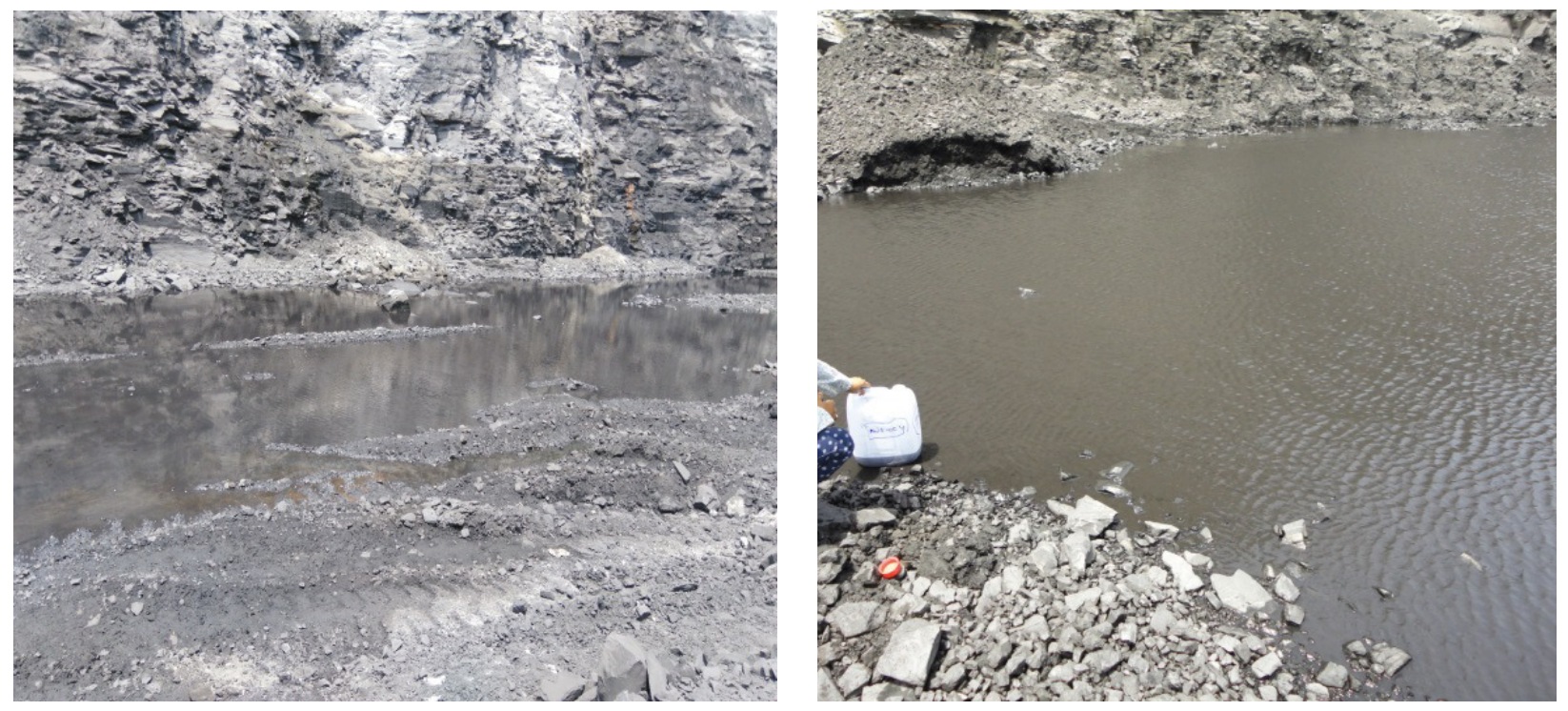

\section{Laboratory Work}

Fig.-2: Water sampling location at Singrauli coalfield

Various methods are available for analyzing the wastewater. These methods largely involve standardized procedures that are often complicated and time-consuming. Good analytical procedures are of prime importance in a water quality monitoring programmes. The method of analysis has been adopted as per as the procedures given in the book "Standard Methods for the Examination of Water and Waste water". The parameter like temperature, $\mathrm{pH}$ and total dissolved solids were analyzed by using multi parameter apparatus (Fig.-3 and 4).

\section{Physio-chemical characteristics of mine water in study areas}

In Kakari open cast project, the analysis of water quality shows that the $\mathrm{pH}$ value ranged from 6.50 to 7.14 shows in (Fig.-6) whereas the concentration of Sulphate is low varied from 182.00 to $205.00 \mathrm{mg} \mathrm{L}^{-1}$ and the iron concentration ranged from 0.34 to $1.42 \mathrm{mg} \mathrm{L}^{-1}$. The concentration of TDS and TSS are showing the Fig.-3. The other parameters i.e. BOD, Oil \& grease and others are well within the permissible limit (Table-1).

\section{Water Pollution Control Measures Adopted in the study area}

Domestic STPs have been constructed in the township with extended aeration process. The plant contains aeration units for oxidation, clarifiers for removal of suspended solids, sludge drying beds, grit removal facilities, sewer lines, manholes, pump houses, control room, etc. Treated water is taken for reuse in tree plantation, horticulture, construction activities. Dried sludge is valuable manure for tree plantation and horticulture works. 
Integrated Industrial ETPs are designed for average discharge from mines, workshops, and CHPs. The plant contains traps for recovery of oil \& grease, clarifiers for removal of suspended solids, flush mixers for chemical dosing, sludge drying beds and pumping arrangements. Treated water is reused for tanker filling, sprinklers, etc. Dried sludge is buried in lined pits.

A substantial amount of silts are carried along with runoff water. Catch drains with silt arrestors are provided in mines area. Those are cleaned at regular intervals. Check dams and siltation ponds are provided to arrest silt flowing into the watercourse. Gabions (loose boulders packed in wire crates) are provided at the toe of the active dumps and across the water course with filter pad to stop silt escape into a water body.

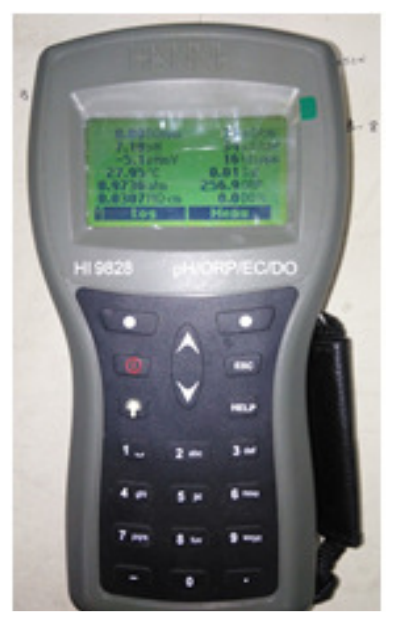

Fig.-3: Multi parameter for water quality analysis

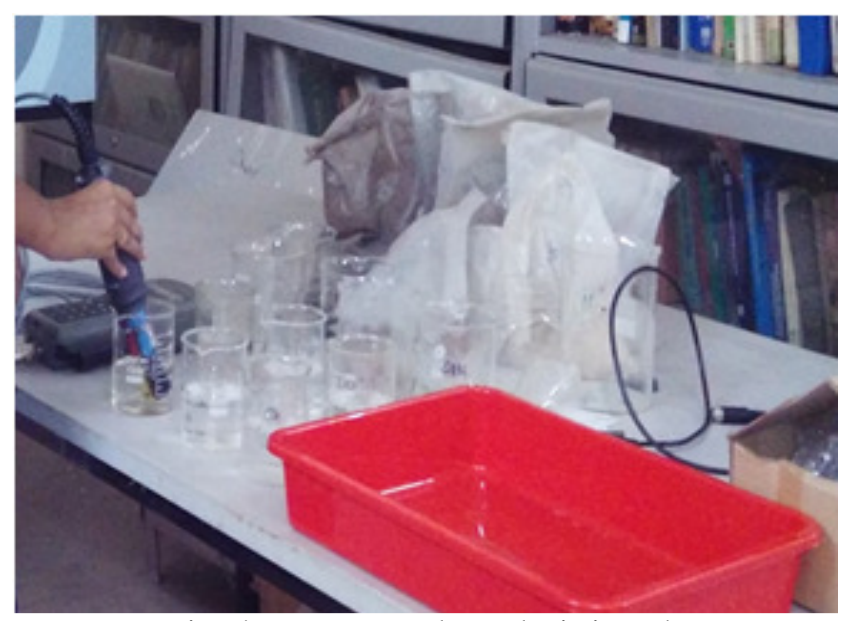

Fig.-4: Water sample analysis in Lab

Table-1: Physico-chemical characteristics of mine water NCL, Singrauli

\begin{tabular}{c|c|c|c|c}
\hline Parameters & $\begin{array}{c}\text { Sump Water } \\
(\mathrm{N}=02)\end{array}$ & $\begin{array}{c}\text { Sump Water- } \\
\text { New } \\
(\mathrm{N}=02)\end{array}$ & $\begin{array}{c}\text { Workshop } \\
\text { Effluent } \\
(\mathrm{N}=03)\end{array}$ & $\begin{array}{c}\text { Workshop Effluent in Nalla } \\
\text { (Drain) } \\
(\mathrm{N}=03)\end{array}$ \\
\hline Temp ${ }^{0} \mathrm{c}$ & 35.00 & 34.00 & 35.00 & 37.00 \\
\hline $\mathrm{pH}$ & 7.14 & 7.12 & 6.53 & 6.70 \\
\hline Colour & - & - & - & Colorless \\
\hline TSS & $278.00 \pm 1.40$ & $265.00 \pm 0.70$ & $1034.00 \pm 1.41$ & $312.00 \pm 0.70$ \\
\hline TDS & $592.00 \pm 1.40$ & $586.00 \pm 0.70$ & $722.00 \pm 1.40$ & $153.00 \pm 0.70$ \\
\hline BOD at $20^{\circ} \mathrm{c}$ & $2.00 \pm 1.40$ & $4.00 \pm 0.70$ & $2.40 \pm 1.10$ & $4.20 \pm 0.50$ \\
\hline DO & $5.00 \pm 1.40$ & $5.40 \pm 1.10$ & $4.80 \pm 0.80$ & $4.00 \pm 0.70$ \\
\hline Oil and Grease & $\mathrm{BDL}$ & $\mathrm{BDL}$ & $10.00 \pm 1.40$ & $4.00 \pm 0.70$ \\
\hline Bio carbonate & $146.00 \pm 1.41$ & $149.00 \pm 0.70$ & $142.00 \pm 1.41$ & $103.00 \pm 0.70$ \\
\hline Carbonate & $16.20 \pm 1.27$ & $17.70 \pm 0.21$ & $12.00 \pm 1.40$ & $19.00 \pm 0.70$ \\
\hline Chloride & $38.00 \pm 1.40$ & $48.00 \pm 0.70$ & $56.00 \pm 1.40$ & $45.00 \pm 0.70$ \\
\hline Sulphate & $18.60 \pm 0.90$ & $205.20 \pm 0.56$ & $78.00 \pm 1.40$ & $58.00 \pm 0.70$ \\
\hline Calcium & $30.30 \pm 1.20$ & $16.20 \pm 0.50$ & $15.00 \pm 1.40$ & $19.30 \pm 0.40$ \\
\hline Iron & $1.35 \pm 1.17$ & $0.34 \pm 0.46$ & $0.58 \pm 1.00$ & $1.42 \pm 0.30$ \\
\hline Magnesium & $45.20 \pm 1.27$ & $49.00 \pm 1.40$ & $23.70 \pm 0.91$ & $18.30 \pm 1.20$ \\
\hline
\end{tabular}

Except for Temperature, $\mathrm{pH}$, and color, all values are in $\mathrm{mg} \mathrm{L}^{-1}$

Used oils are collected in lid tight steel drums which are stored on a paved platform covered with shed. Floating oils recovered from oil \& grease traps are collected in drums and stored on a raised paved platform having drains to collect back spillages. 


\section{Utilization of treated mine water in mines}

Coal can be mined from deep underground caverns, surface pits or from mountain tops. Depending on its quality, coal may need to be "washed" with water and chemicals to remove sulfur and impurities before it can be burned in a power plant.

The role of water sprays in mining is a dual one:

i. Wetting, of the broken material being transported and,

ii. Airborne capture, of the two, wetting of the broken material is far more effective.

Adequate wetting is extremely important for dust control. The vast majority of dust particles created during breakage is not released into the air, but stay attached to the surface of the broken material ${ }^{4}$. Under actual mining conditions, the typical water spray operating at $100 \mathrm{psi}$ and 1-2 gpm give no more than $30 \%$ airborne capture of respirable dust.

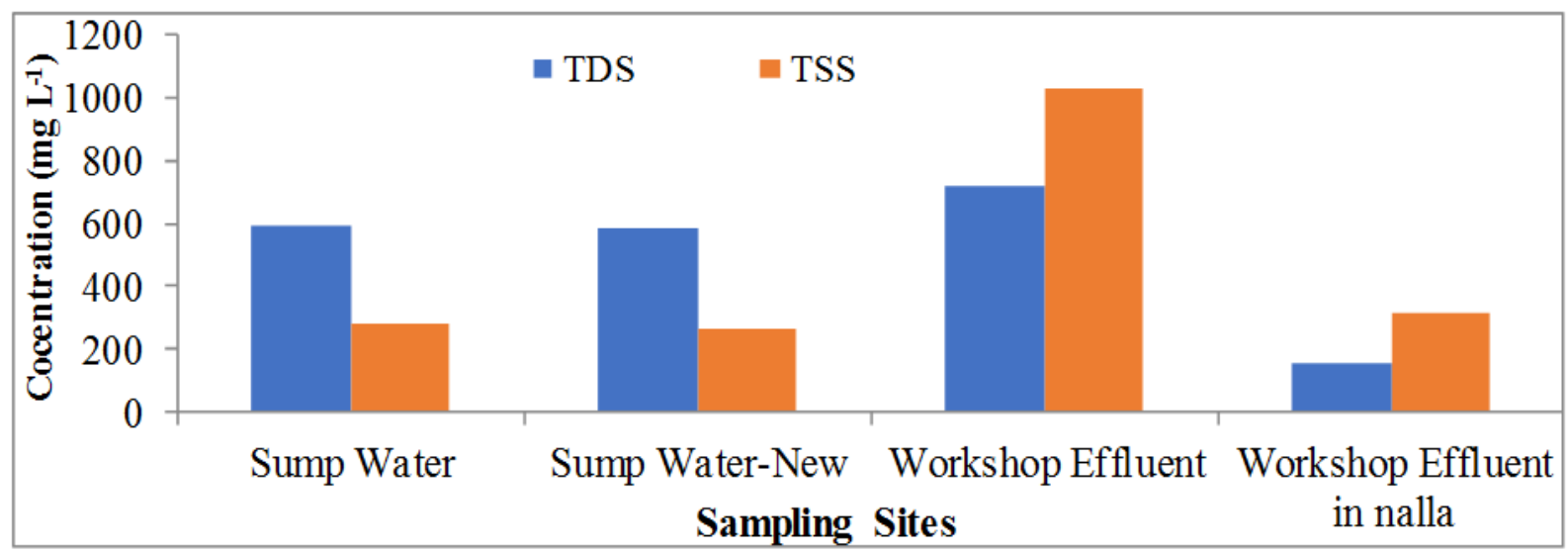

Fig.-5: Concentration of TDS and TSS in Mine water

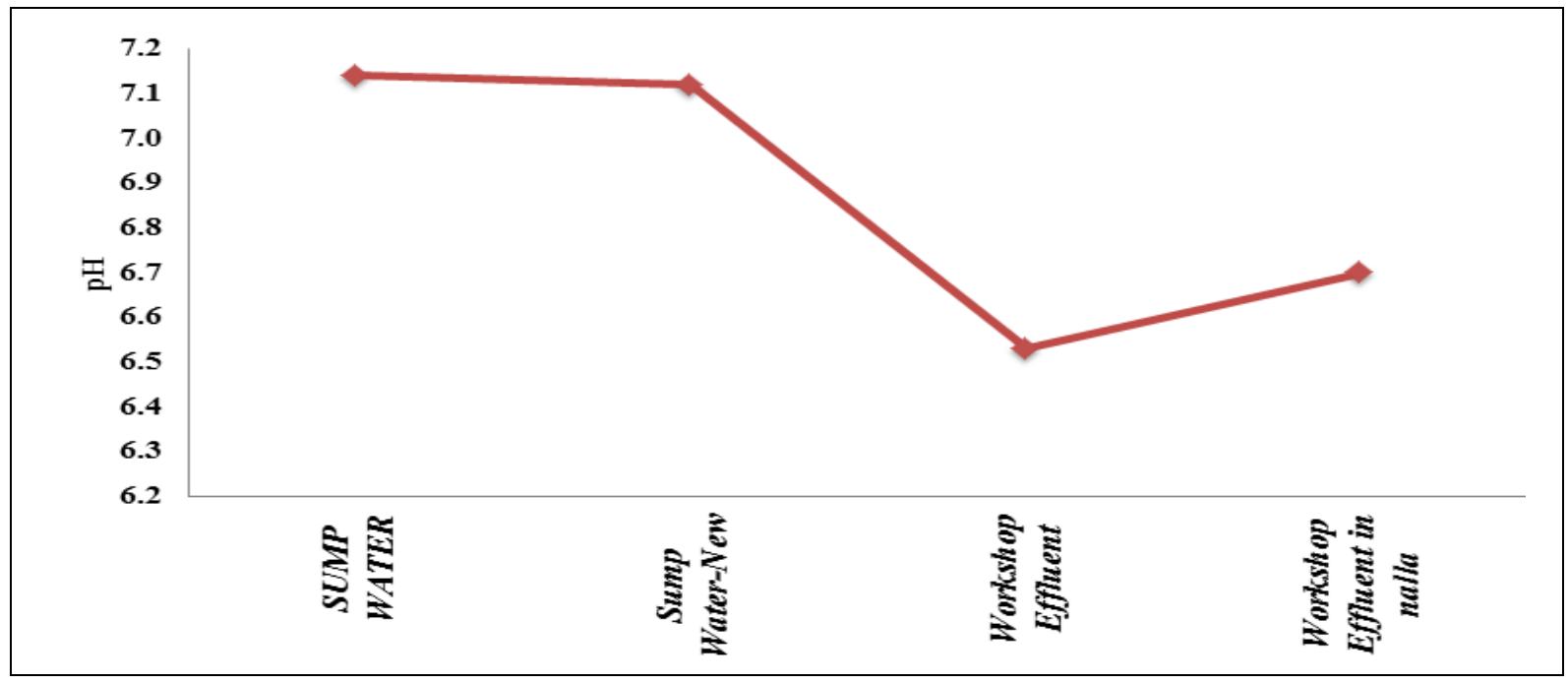

Fig.-6: $\mathrm{pH}$ of Mine water

Depending on the size of the vehicle and conditions at the mine site, it can take between 8-15 hours to clean each piece of equipment. Using the Washman concept to clean dozers, haul pack trucks and other heavy-duty equipment can easily reduce the cost of washing by over $80 \%$. Washing dirty bulldozers and other heavy duty equipment usually takes anywhere from 2-8 hours. 
Disposal of mine wastewater has become a problem of increasing importance from an ecological point of view. Results indicate that neutralized acid mine drainage can be used successfully for irrigation of a large variety of crops. Management of plant nutrition is important when irrigating with mine waters and it is essential to take into account the ions that are being added with the water ${ }^{5}$.

\section{CONCLUSION}

Awareness of environmental impacts and concern for the environment has increased in recent time. Water management strategies are used to minimize the environmental impact of mining operations and are now at the heart of mine development, operation, and restoration activities. Protection of water quality, the original purpose of pollution control continues to be the primary main objective in the mining industry at present. However, preservation of water resources, protection of physicochemical characteristics of downstream and maintenance of recreational water are additional priorities in and around a mining industry.

The disposal of wastewater from mine workshop, coal handling plant and from coal preparation plants is among the most common severe problem associated with coal mining. In this study, all the water quality parameters measured are found to be in the eco-friendly state. The physicochemical characteristics of mine water are within the permissible limit. All the control measures taken by the surrounding industry are quite effective. Treated water is taken for reuse in tree plantation, horticulture, construction activities, tanker filling and sprinklers.

\section{ACKNOWLEDGMENT}

The corresponding author would like to thanks, Department of Mining Engineering, Indian Institute of Technology (Banaras Hindu University), Varanasi and thanks to Ministry of Human Resource Development, Government of India, for providing Institute Assistantship.

\section{REFERENCES}

1. N.Z. Jovanovic, R.O. Barnard, N.F.G. Rethman, and J.G. Annandale, Water SA, 24(2), 113(1998)

2. J.R. Macknick, R. Newmark, G. Heath, and K.C. Hallet, Environ. Res. Lett., 7, 045802(2012), DOI: 10.1088/1748-9326/7/4/045802

3. S. Shirin, and A.K. Yadav, Curr. World Environ., 9(2), 536(2014), DOI: 10.12944/CWE.9.2.39

4. J. Meldrum, S. Nettles-Anderson, G. Heath, and J. Macknick, Environ. Res. Lett., 8 015031(2013), DOI: $10.1088 / 1748-9326 / 8 / 1 / 015031$

5. S. Shirin and A. Jamal, Rasayan J. Chem., 11(1), 74(2018), DOI: 10.7324/RJC.2018.1111957

[RJC-1998/2018] 